\title{
Pesquisa científica, inovação e desenvolvimento
}

\author{
Cristina Muccioli, Mauro Campos, Mauro Goldchmit, Paulo E.C. Dantas, Samir J. Bechara, Vital Paulino Costa
}

Inovação e conhecimento representam importantes fatores para o desenvolvimento e competitividade de países e empresas. O conhecimento novo propicia, através da sua aplicação prática e inovadora, a geração de produção e renda.

Gerado pela atividade acadêmica e pela pesquisa científica, o conhecimento novo materializa-se em publicações e teses. Não tem valor econômico efetivo, pois, enquanto mero conhecimento, não compete, no mercado, com as alternativas tecnológicas existentes.

No plano da Biotecnologia, pode o conhecimento novo assumir diferentes formatos. Originado pela pesquisa científica, pode consistir, entre outros, de uma nova expressão genética de uma doença, de um novo polímero ou de um novo composto antimicrobiano. Este bem jurídico vem protegido pelo direito autoral, que o vincula ao seu autor(es) e/ou instituição. O direito autoral materializa-se na publicação formal em periódicos científicos, como os Arquivos Brasileiros de Oftalmologia.

Numa segunda etapa, igualmente importante, converte-se o conhecimento novo em uma ou várias aplicações industriais. A nova expressão genética gera um teste diagnóstico para uma doença. O novo polímero, uma nova lente de contato gelatinosa. O novo composto antimicrobiano, um novo remédio. Todos com potencial aplicação industrial e empresarial, para a geração de riquezas. Este potencial será tanto maior quanto maior for a vantagem competitiva do novo produto diante dos demais já existentes no mercado. Nesta fase é que se consolida a inovação gerada pelo conhecimento novo. Esta inovação, fundamentada no potencial industrial e comercial do novo produto, vem protegida pelo direito industrial. Materializa-se no registro de uma patente, que restringe a exploração do produto ao autor(es) e/ou instituição que a detém.

A um mesmo conhecimento científico novo, podem corresponder diversas inovações. O mesmo polímero pode permitir a fabricação de diferentes modelos de lentes de contato, de aplicações clínicas e comerciais diversas. As sucessivas inovações aprimoram o produto, adicionando competitividade, para disputar com outras tecnologias do mesmo produto, uma parcela do mercado. Portanto, cada inovação não implica um conhecimento novo, mas sim o uso criativo, para um caso específico, de conhecimentos já existentes. A propulsão do avião, em cem anos, teve apenas três descobertas mais relevantes: a hélice, o turbo-hélice e o jato. Mas o número de inovações conta-se aos milhares.
Não necessariamente o detentor da invenção e da inovação são os mesmos. A Coréia domina o mercado de monitores, mas não descobriu nenhuma das tecnologias contidas nas telas. A Embraer não descobriu o avião, mas lidera o mercado com importantes inovações de aplicação específica.

Diferencia-se, portanto, a inovação da geração do conhecimento científico novo. Este, ato acadêmico de pesquisa básica, realizado no âmbito da universidade, publicável em periódicos especializados, como prova de sua originalidade. Aquele, atividade criativa, destinada a dar mais competitividade a uma aplicação do conhecimento novo, no intuito de conquistar ou ampliar sua parcela de mercado, agregando valor econômico e lucratividade.

O conhecimento novo não tem viabilidade de mercado sem as inovações. Segue, pois, ser a inovação o real mecanismo de agregação de valor econômico, na medida em que transforma uma descoberta em um produto ou processo capaz de disputar o mercado.

A geração de conhecimento exige planejamento adequado, políticas públicas de fomento e emprego de recursos. A descoberta científica consome muitos anos para conquistar formato tecnológico suficiente a disputar mercado. Por vezes, este objetivo não é alcançado, a descoberta acaba definitivamente abandonada e perdem-se os recursos investidos.

O principal parâmetro de medida do grau de inovação é a obtenção de patentes de invenção. Nas últimas décadas, nosso país tem mostrado resultados inferiores a outros competidores, como Taiwan, Coréia, China e Índia, entre outros, que vêm crescendo através da inovação própria. Nosso desafio é gerar inovações tecnológicas capazes de propiciar, à nossa produção, valor econômico agregado e competitividade nos mercados internacionais. Para vencer esse desafio, contamos com órgãos públicos de fomento, a financiar nossos laboratórios e pesquisadores.

Inovação não é privilégio de países avançados, dotados de indústrias de alta tecnologia. Pode e deve ser uma prática estimulada em países emergentes, como o Brasil. O mercado médico representa uma importante perspectiva e, no âmbito da Oftalmologia, os Arquivos Brasileiros de Oftalmologia, particularmente após a conquista do Index Medicus, podem contribuir significativamente, enquanto espaço para a exposição e disseminação do conhecimento novo brasileiro. 